\title{
Analgesic effect of the bi-level injection erector spinae plane block after breast surgery: A randomized controlled trial
}

\author{
İki seviye erektör spina plan bloğunun meme cerrahisi sonrası analjezik etkisi: \\ Randomize kontrollü çalışma
}

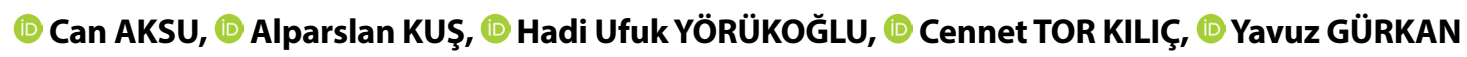

\begin{abstract}
Summary
Objectives: Due to the complex breast innervation, postoperative analgesia after breast surgery is a challenge for the anesthesiologists. The erector spinae plane block (ESPB) is a newly defined promising technique for this purpose. The main purpose of this study was to evaluate the analgesic efficacy of the ultrasound-guided ESPB in breast surgery, monitoring its effect on the postoperative opioid consumption.

Methods: Fifty female patients, who were scheduled to undergo elective breast surgery, with the American Society of Anesthesiology physical score I-II, and aged between 25 and 70 years, were included into the study. Patients were randomized into two groups, as the ESPB and the control group. All patients in the ESPB group received a bi-level (T2-T4) ultrasound-guided ESPB with $20 \mathrm{ml} 0.25 \%$ bupivacaine (10 ml for each level) preoperatively. An intravenous patient-controlled analgesia device for the postoperative analgesia was given to all patients. The numeric rating scale (NRS) scores for pain and postoperative morphine consumptions were recorded at the $1^{\text {st }}, 6^{\text {th }}, 12^{\text {th }}$, and $24^{\text {th }}$ hour postoperatively.

Results: Postoperative morphine consumption was significantly lower in the ESPB group compared to the control group at the postoperative $6^{\text {th }}, 12^{\text {th }}$, and $24^{\text {th }}$ hour ( $p<0.001$ for each time interval). The morphine consumption at the 24 -hour was reduced by $75 \%$. There was no significant difference in the NRS scores (median NRS values were 2, 1, 0, 0, and 2, 2, 1, 1, respectively).

Conclusion: Our study has shown that a significant opioid-sparing analgesic effect in patients undergoing breast surgery could be achieved with a US-guided bi-level ESP block.
\end{abstract}

Keywords: Breast cancer surgery; erector spinae plane block; postoperative pain

\begin{abstract}
Özet
Amaç: Memenin kompleks innervasyonuna bağlı olarak meme cerrahisinden sonra postoperatif analjezi sağlamak anestezistler için zorlu bir durumdur. Erektör spina plan bloğu (ESPB), yeni tanımlanmış ve bu amaç için umut verici bir tekniktir. Bu çalışmanın amacı, ultrason eşliğinde uygulanan ESPB'nun meme cerrahisindeki analjezik etkinliğini, postoperatif opioid tüketimi üzerine etkisine bakarak değerlendirmektir.

Gereç ve Yöntem: Çalışmaya elektif meme cerrahisi planlanan, Amerikan Anesteziyoloji Derneği (ASA) fiziksel skoru l-II ve yaşları 25 ile 70 arasında olan 50 kadın hasta dahil edildi. Hastalar ESPB ve Kontrol grubu olarak iki gruba ayrıldı. ESPB grubundaki tüm hastalara, preoperatif, $20 \mathrm{ml} \% 0.25$ bupivakain (her seviye için $10 \mathrm{ml}$ ) ile iki seviye (T2-T4) ultrason eşliğinde ESPB yapıldı. Tüm hastalara postoperatif analjezi için intravenöz hasta kontrollü analjezi cihazı verildi. Numerik ağrı skalası (NRS) skorları ve postoperatif morfin tüketimleri 1, 6, 12 ve 24 'üncü saatlerde kaydedildi.

Bulgular: Postoperatif morfin tüketimi ESPB grubunda kontrol grubuna göre postoperatif 6., 12. ve 24. saatlerde anlamlı olarak düşüktü (tüm zaman aralıkları için $\mathrm{p}<0.001$ ). Yirmi dördüncü saatteki morfin tüketimi \%75 azaldı. NRS skorlarında anlamlı fark yoktu (sırasıyla median NRS değerleri 2, 1, 0, 0 ve 2, 2, 1, 1 idi).

Sonuç: Çalışmamız göstermiştir ki; meme cerrahisi geçiren hastalarda ultrason eşliğinde iki seviye ESPB ile opioidden bağımsız analjezik etki sağlanabilir.

Anahtar sözcükler: Erektör spina plan bloğu; meme kanseri cerrahisi; postoperatif ağrı.
\end{abstract}

Department of Anesthesiology and Reanimation, Kocaeli University, Kocaeli, Turkey

Submitted (Başvuru tarihi) 18.10.2018 Accepted after revision (Düzeltme sonrası kabul tarihi) 17.01.2019 Available online date (Online yayımlanma tarihi) 02.07.2019

Correspondence: Dr. Can Aksu. Kocaeli Üniversitesi Tıp Fakültesi, Anesteziyoloji ve Reanimasyon Anabilim Dalı, Kocaeli, Turkey.

Phone: +90 - 533 - 2568290 e-mail:dr.aksu@gmail.com

(C) 2019 Turkish Society of Algology

(c) (i) (8)

This work is licensed under a Creative Commons Attribution-NonCommercial 4.0 International License. 


\section{Introduction}

Breast cancer is the most common cancer type and also the second most cause of cancer dependent deaths in women. ${ }^{[1]}$ Therefore breast surgeries are one of the most common surgeries performed in daily practice. ${ }^{[2]}$ Depending on dissections of both thoracic and axillary region, postoperative pain constitutes a major problem for anesthetists. Complex innervation of the breast makes management of postoperative pain even more complicated. Type of surgery is important to understand the neural origin of pain. While postoperative pain after lumpectomy surgery derives mainly from intercostal nerves and supraclavicular nerve, origin of pain after modified radical mastectomy (MRM) involves also brachial plexus. ${ }^{[3]}$

Many regional techniques, like paravertebral block $(P V B)$, pectoral nerves block (PECs), serratus plane block (SPB) were described in the literature for maintaining postoperative analgesia. ${ }^{[3]}$ Among all these regional anesthesia techniques PVB is the most studied and found to be effective regional technique for this purpose..$^{[3]}$ Due to its anatomic proximity to pleura and central neuroaxial system, it's also one of the most challenging techniques.

In 2016 Forero et al. ${ }^{[4]}$ described erector spinae plane block (ESPB) for thoracic analgesia. Since than many different uses of this technique have been reported. ${ }^{[5-10]}$ There were only a few case reports in the literature about ESPB use in breast surgeries. ${ }^{[11,12]}$ Recently study of Gürkan et al. ${ }^{[13]}$ has shown that, with a single level injection of ESPB, postoperative morphine consumption after breast surgeries had significantly decreased compared to control group. Our hypothesis was that, it would be better to do this block at two levels to achieve a better spread of local anesthetics to cover up the whole surgical area (including axillary zone). We aimed to evaluate the analgesic effect of US guided bi-level ESPB for breast cancer surgery, regarding to morphine consumption at postoperative 24 hours. Secondary aims of the study were to compare the incidence of opioid-related side effects, postoperative nausea and vomiting (PONV) and pain scores.

\section{Materials and Methods}

This study was done after obtaining local Ethic Committee's permission (KIA 2017-377). Patients' written informed consents were obtained. The study was registered prior to patient enrollment with clinicaltrials.gov (NCT03415646) on January 2018.

Fifty female patients who were to go elective breast cancer surgery were included into the study. Patients were aged between 25 and 70 years with American Society of Anesthesiology (ASA) physical score I-II. Patients with known allergies to any of the study drugs, infection of the skin at the site of needle puncture area; coagulopathy, obesity (body mass index $>35 \mathrm{~kg} / \mathrm{m}^{2}$ ) and chronic use of opioids were excluded from the study.

Sequentially numbered opaque sealed envelope technique was used for randomization and patients were randomized to one of the two groups as ESPB group and Control group. ${ }^{[14]}$ All patients in ESPB group received bi-level ESPB and patients in Control group received no intervention. Midazolam $0.03 \mathrm{mg}$ kg-1 iv was used for premedication of patients upon arrival to the preoperative holding area.

\section{ESPB Technique}

Blocks were performed approximately 20 min before induction of general anesthesia in the preoperative holding area. Blocks were performed unilaterally in the prone position with technique described by Chin et al. ${ }^{[15]} 10 \%$ povidone iodine was used for skin preparation. Same two anesthesiologists (YG, CA) were performed all the blocks. These two anesthesiologists were also blinded to the rest of the study (data collection, intraoperative management etc.). Blocks were performed with large bandwidth, multifrequency convex probe (1-8 MHz) of Esaote My Lab 6 US machine (Florence, Italy) with a 22G, $50 \mathrm{~mm}$, insulated facet type needle (BBraun Sonoplex, Melsungen, Germany). Using an in-plane approach, blocks were done at $\mathrm{T} 2$ and $\mathrm{T} 4$ levels of spine.

With a sagittal approach, probe was placed $2-3 \mathrm{~cm}$ lateral to the midline. After identifying the transverse processes and erector spinae muscle, the needle was inserted with a cranial to caudal direction to the deep of the erector spinae muscle (Fig. 1). The correct position of the needle tip was confirmed with the administration of $0.5-1 \mathrm{ml}$ of local anesthetic (LA) and than $10 \mathrm{ml}$ of $0.25 \%$ bupivacaine was administered. Same procedure was repeated for the second level of the block performance. Both cranial and caudal LA spread was observed. 


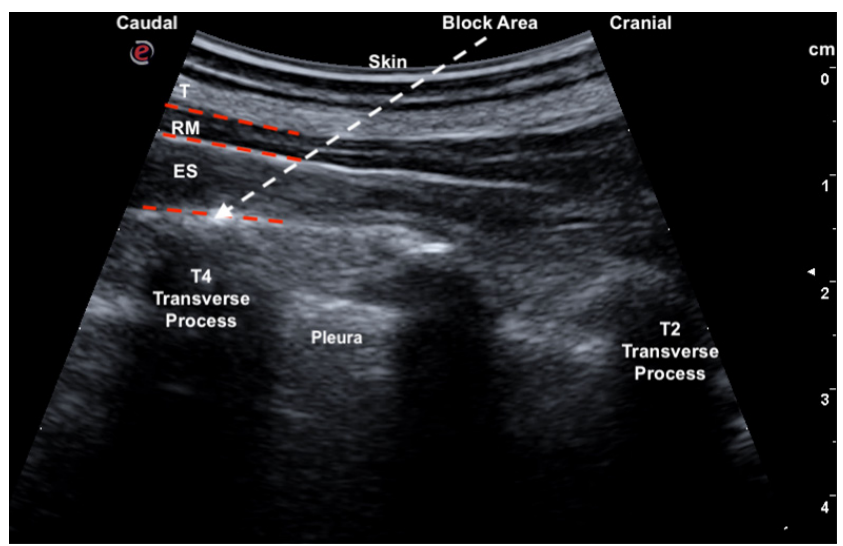

Figure 1. Ultrasound image of the block area. T: Trapezius Muscle; RM: Rhomboid Major Muscle; ES: Erector Spinae Muscle.

\section{General Anesthesia}

Perioperative anesthesia management was done according to departmental guidelines. Propofol (2-3 $\mathrm{mg} / \mathrm{kg}$ ) and fentanyl ( $2 \mathrm{mg} / \mathrm{kg}$ ) iv were used for general anesthesia induction. Rocuronium $0.6 \mathrm{mg} / \mathrm{kg}$ was administered iv for tracheal intubation. Combination of desflurane with nitrous oxide in oxygen $(2: 1)$ in $3 \mathrm{~L}$ of fresh gas flow was used for anesthesia maintenance. At the end of the surgery paracetamol $1 \mathrm{~g}$ and tramadol $100 \mathrm{mg}$ iv were administered for providing postoperative analgesia and also Ondansetron $8 \mathrm{mg}$ was given for the prevention of postoperative nausea and vomiting.

Numeric rating scale (NRS) ranging from 0 (no pain) to 10 (worst imaginable pain) was used for postoperative pain assessments. A patient controlled analgesia device (PCA) containing morphine $0.5 \mathrm{mg} / \mathrm{ml}$, which was set to deliver $1 \mathrm{mg}$ bolus dose morphine, with 8 min lockout time and $6 \mathrm{mg} 1 \mathrm{~h}$ limit was given to all patients upon arrival to the recovery room.

A pain nurse, who was blinded to the study, recorded NRS scores at postoperative 1, 6, 12 and $24 \mathrm{~h}$. Same nurse also recorded total morphine consumptions during the $24 \mathrm{~h}$ postoperative period and the incidence of PONV.

\section{Statistical Analysis}

Sample size analyze was done according to a preliminary study in our clinic which has shown that the mean $( \pm S D)$ morphine consumption in the postoperative $24 \mathrm{~h}$ was $16.6 \pm 6.92$. The sample size necessary to detect a $30 \%$ difference in postoperative morphine requirement with $80 \%$ power and an error of 0.05 was found as 20 subjects per group. For securing patient dropouts 25 patients were included in each group.

IBM SPSS for Windows ${ }^{\circledast}$ version 20.0 (SPSS, Chicago, IL, USA) was used for all statistical analyses. For the normality of data distribution Kolmogorov-Smirnov tests were used. Categorical variables were expressed as counts (percentages) and continuous variables were expressed as mean \pm standard deviation, median $\left(25^{\text {th }}\right.$ $75^{\text {th }}$ percentiles). Between group analyses, Student's $t$ test was used for comparisons of normally distributed continuous variables and Mann Whitney $U$ Test was used for non-normally distributed continuous variables. Monte Carlo Chi Square tests, Yates' Chi Square test and Fisher's Exact Chi Square test were used for the comparisons of categorical variables. A two-sided $P$ value $<0.05$ was considered statistically significant.

\section{Results}

A total of 50 patients were enrolled in the study (Fig. 2). Demographical data, durations and types of surgeries were similar in two groups (Table 1).

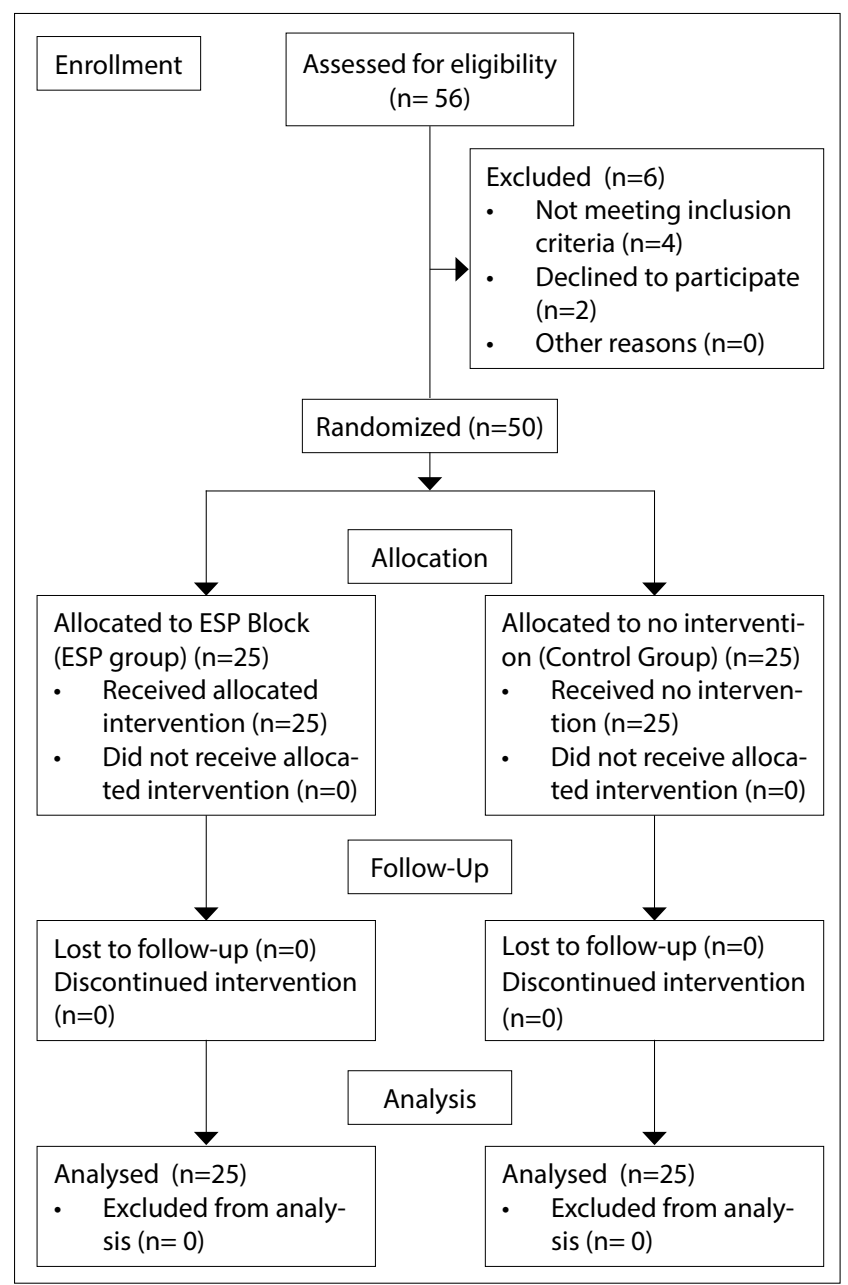

Figure 2. Consort flow diagram. 
Morphine consumptions in postoperative $6^{\text {th }}, 12^{\text {th }}$ and $24^{\text {th }}$ hours have significantly decreased in ESPB group ( $p<0.05$ for each time interval). At postoperative $24 \mathrm{~h}$, mean morphine consumptions were $3.02 \pm 2.06 \mathrm{mg}$ in the ESPB group, and $13.2 \pm 4.98 \mathrm{mg}$ in the Control group. Even though ESPB group had lower pain scores at all times, there was no statistically significant difference between the groups on NRS scores (Table 2).

At postoperative $12^{\text {th }}$ hour $52 \%$ and at postoperative $24^{\text {th }}$ hour $64 \%$ of the patients were pain-free (NRS=0) in ESPB group while it was $40 \%$ and $32 \%$ of the pa-

Table 1. Demographic data

\begin{tabular}{lccc}
\hline & $\begin{array}{c}\text { ESPB group } \\
(\mathbf{n = 2 5 )}\end{array}$ & $\begin{array}{c}\text { Control group } \\
(\mathbf{n = 2 5 )}\end{array}$ & $\mathbf{p}$ \\
\hline Age (year) & $51.76 \pm 9.03$ & $51.52 \pm 10.79$ & 0.932 \\
Weight $(\mathrm{kg})$ & $71 \pm 9.38$ & $70.84 \pm 11.27$ & 0.957 \\
Height $(\mathrm{cm})$ & $159 \pm 4.8$ & $159.52 \pm 6.20$ & 0.742 \\
BMI $\left(\mathrm{kg} / \mathrm{m}^{2}\right)$ & $28.05 \pm 3.22$ & $27.86 \pm 4.54$ & 0.832 \\
ASA $(\mathrm{I} / \mathrm{II})$ & $14 / 11$ & $11 / 14$ & 0.406 \\
Duration of & $99 \pm 23.71$ & $93.6 \pm 23.07$ & 0.419 \\
surgery $(\mathrm{min})$ & & & \\
Type of & $15 / 5 / 1 / 4$ & $13 / 6 / 0 / 6$ & 0.795 \\
surgery $(1 / 2 / 3 / 4)$ & & & \\
\hline
\end{tabular}

Data were presented as mean \pm standart deviation. Surgery types: 1- Modified Radical Mastectomy; 2- Simple mastectomy + Sentinel Lymph Node Biopsy (SLNB); 3- Lumpectomy + SLNB; 4- Lumpectomy + Axillary dissection.

Table 2. Postoperative NRS scores and morphine consumptions in the first 24-hour

\begin{tabular}{cccc}
\hline & $\begin{array}{c}\text { ESPB group } \\
(\mathbf{n = 2 5})\end{array}$ & $\begin{array}{c}\text { Control group } \\
(\mathbf{n}=\mathbf{2 5})\end{array}$ & $\mathbf{p}$ \\
\hline NRS scores & & & \\
$1^{\text {st }}$ hour & $2(0-3.5)$ & $2(0-4)$ & 0.928 \\
$6^{\text {th }}$ hour & $1(0-2)$ & $2(0-2)$ & 0.326 \\
$12^{\text {th }}$ hour & $0(0-2)$ & $1(0-3)$ & 0.210 \\
$24^{\text {th }}$ hour & $0(0-1.5)$ & $1(0-2)$ & 0.099 \\
Morphine consumption (mg) & & \\
$1^{\text {st }}$ hour & $1(1-1)$ & $1(0.5-1)$ & 0.428 \\
$6^{\text {th }}$ hour & $2(1-2.5)$ & $4(3-6.5)$ & $<0.001$ \\
$12^{\text {th }}$ hour & $3(1-3)$ & $8(4.5-10.5)$ & $<0.001$ \\
$24^{\text {th }}$ hour & $3(1-5)$ & $12(10-16)$ & $<0.001$ \\
\hline
\end{tabular}

Data were presented as median (percentiles 25-75). tients (respectively) in Control group. Also in ESPB group 10 patients (40\%) didn't use any opioid after postoperative 6th hour, but in Control group there were only one patient (4\%).

There were seven patients in ESPB group who experienced postoperative nausea and 6 of them also had vomiting. Nausea was seen in 6 patients in Control group and 4 of them had also vomiting. There was no significant difference for PONV. No complications were observed during the study period.

\section{Discussion}

Our study has clearly shown that two levels ESPB has significantly decreased the morphine consumption in postoperative $6^{\text {th }}, 12^{\text {th }}$ and $24^{\text {th }}$ hours. Decrease in total morphine consumption at postoperative 24 hours was $75 \%$ compared to Control group.

There were many studies in the literature about maintaining postoperative analgesia with regional anesthesia techniques after breast surgeries. Frequency of this surgery and challenging sensory innervation of the breast makes this quest stand still fresh. Although PVB has been commonly accepted as the most effective regional technique for this indication, clinicians are in the search of a safer and easier alternative. Pectoral nerve blocks (PECs I and PECs II) were introduced in clinic for this purpose. ${ }^{[16,17]}$ Afterwards; serratus plane block was also described by Blanco et al. ${ }^{[18]}$ with the goal of providing extended intercostal nerve coverage.

ESPB was first defined as an analgesic technique for thoracic neuropathic pain by Forero et al. ${ }^{[4]}$ In that manuscript, the authors also studied the spread of dye in two fresh cadavers and reported that the spread of the dye reached both to ventral and dorsal rami of spinal nerves, which could cause a sensory blockade over the anterolateral thorax. Adhikary et al. ${ }^{[19]}$ showed that LA spread after ESPB could be as 2 to 5 level epidural and 5 to 9 level intercostal. This could explain the mechanism of this block but further studies with larger samples are needed to verify these findings.

There were many studies with controversial results in the literature about the effect of both single or multilevel paravertebral blocks on postoperative pain 
after breast surgeries. ${ }^{[20-23]}$ While some studies ${ }^{[21,22]}$ claim no difference in opioid consumption; some others ${ }^{[20,23]}$ claim superior analgesia with less opioid consumption with paravertebral block. In contrast with paravertebral block, as ESPB is a newly defined regional technique, there were only one randomized controlled study and a few case reports about its use in breast surgeries..$^{[8,9,13,24]}$ Two reports were ${ }^{[8,9]}$ single shot ESPB, while one of them ${ }^{[24]}$ was a single shot block with a continuous LA infusion via catheter. All these reports found ESPB as an effective analgesia method. Study of Gürkan et al. ${ }^{[13]}$ reported that a single shot ESPB with $20 \mathrm{ml}$ of LA at T4 level could decrease morphine consumption. It was shown that mean morphine consumption at postoperative 24 hour was $5.76 \mathrm{mg}$ while it was $16.6 \mathrm{mg}$ in control group. A $65 \%$ decrease was found as both statistically and clinically significant. In our current study where bi-level injections were performed morphine consumptions were found $3.02 \pm 2.06$ and $13.2 \pm 4.98$ respectively. Bi-level injection decreased opioid consumption up to $75 \%$ in 24 hours. Our results correlated with our hypothesis and showed that bi-level ESP block can further decrease opioid requirements.

Even though the morphine consumption was decreased in the ESPB group compared to control group, it was not enough to provide significant difference on PONV. As it was described in the analysis of Apfel et al., ${ }^{[25]}$ there were other risk factors for PONV in our study, which could be the possible explanation of this situation, like female gender and duration of anesthesia with volatile anesthetics.

Although the research has reached its aims; there were some limitations of this study. First of all patients were not fully blinded to the study. Even the patients were under sedation while the blocks were done, the patients might know that whether they had an injection for ESPB or not. For observing and comparing the placebo effect it might be better to perform a sham block to control group. Secondly, for knowing the exact limits of the block, a sensory testing for the mapping of block area should have been performed. We think these limitations could and should be the aims of future studies.

For achieving wide spread of LA, due to complex sensory innervation of breast surgical area, we have chosen two level injection at T2 and T4 spine levels. T2 level selection, as the second level of injection point, was depending on the fact that axillar surgery area is in the territory of the lateral cutaneous branch of T2. ${ }^{[3]}$ Even we found a significant difference in morphine consumptions, the spread of LA should be studied to know the limits of local anesthetic distribution.

\section{Conclusions}

This study has shown that ultrasound guided bi-level ESPB is effective for providing postoperative analgesia after breast cancer surgeries and it significantly reduced opioid consumption compared to control group. This opioid sparing effect of bi-level ESPB is promising for that it is one of the main goals of enhanced recovery after surgery (ERAS) protocols. ${ }^{[26]}$ We think that single level ESPB should be compared to multiple level ESPB to choose the best clinical practice for breast surgery.

\section{Conflict-of-interest issues regarding the authorship or article: None declared.}

\section{Peer-rewiew: Externally peer-reviewed.}

\section{References}

1. Carlson GW, Wood WC. Primary treatment of breast cancer. In: Aston SJ, Beasley RW, Thorne CNM. Grabb and Smith's Plastic Surgery. 5th ed. Philadelphia, Lippincott-Raven; 1997.

2. DeSantis $C E$, Lin $C C$, Mariotto $A B$, Siegel $R L$, Stein $K D$, Kramer JL, et al. Cancer treatment and survivorship statistics, 2014. CA Cancer J Clin 2014;64(4):252-71. [CrossRef]

3. Woodworth GE, Ivie RMJ, Nelson SM, Walker CM, Maniker RB. Perioperative Breast Analgesia: A Qualitative Review of Anatomy and Regional Techniques. Reg Anesth Pain Med 2017;42(5):609-31. [CrossRef]

4. Forero M, Adhikary SD, Lopez H, Tsui C, Chin KJ. The Erector Spinae Plane Block: A Novel Analgesic Technique in Thoracic Neuropathic Pain. Reg Anesth Pain Med 2016;41(5):621-7. [CrossRef]

5. Chin KJ, Malhas L, Perlas A. The Erector Spinae Plane Block Provides Visceral Abdominal Analgesia in Bariatric Surgery: A Report of 3 Cases. Reg Anesth Pain Med 2017;42(3):3726. [CrossRef]

6. Aksu C, Gürkan Y. Ultrasound guided erector spinae block for postoperative analgesia in pediatric nephrectomy surgeries. J Clin Anesth 2018;45:35-6. [CrossRef]

7. Cesur S, Ay AN, Yayık AM, Naldan ME, Gürkan Y. Ultrasoundguided erector spinae plane block provides effective perioperative analgesia and anaesthesia for thoracic mass excision: A report of two cases. Anaesth Crit Care Pain Med 2019;38(2):189-90. [CrossRef] 
8. Aksu C, Gürkan Y. Ultrasound-guided bilateral erector spinae plane block could provide effective postoperativeanalgesia in laparoscopic cholecystectomy in paediatric patients. Anaesth Crit Care Pain Med 2019;38(1):87-8.

9. Tulgar S, Kapakli MS, Senturk O, Selvi O, Serifsoy TE, Ozer Z. Evaluation of ultrasound-guided erector spinae plane block for postoperative analgesia in laparoscopic cholecystectomy: A prospective, randomized, controlled clinical trial. J Clin Anesth 2018;49:101-6. [CrossRef]

10. Aksu C, Gürkan Y. Opioid sparing effect of Erector Spinae Plane block for pediatric bilateral inguinal hernia surgeries. J Clin Anesth 2018;50:62-3. [CrossRef]

11. Bonvicini D, Tagliapietra L, Giacomazzi A, Pizzirani E. Bilateral ultrasound-guided erector spinae plane blocks in breast cancer and reconstruction surgery. J Clin Anesth 2018;44:3-4. [CrossRef]

12. Veiga $M$, Costa $D$, Brazão I. Erector spinae plane block for radical mastectomy: A new indication? [Article in English, Spanish]. Rev Esp Anestesiol Reanim 2018;65(2):112-5.

13. Gürkan Y, Aksu C, Kuş A, Yörükoğlu UH, Kılıç CT. Ultrasound guided erector spinae plane block reduces postoperative opioid consumption following breast surgery: A randomized controlled study. J Clin Anesth 2018;50:65-8. [CrossRef]

14. Doig GS, Simpson F. Randomization and allocation concealment: a practical guide for researchers. J Crit Care 2005;20(2):187-91. [CrossRef]

15. Chin KJ, Adhikary S, Sarwani N, Forero M. The analgesic efficacy of pre-operative bilateral erector spinae plane (ESP) blocks in patients having ventral hernia repair. Anaesthesia 2017;72(4):452-60. [CrossRef]

16. Blanco R. The 'pecs block': a novel technique for providing analgesia after breast surgery. Anaesthesia 2011;66(9):847-8.

17. Blanco R, Fajardo M, Parras Maldonado T. Ultrasound description of Pecs II (modified Pecs I): a novel approach to breast surgery. Rev Esp Anestesiol Reanim 2012;59(9):470-5.

18. Blanco R, Parras T, McDonnell JG, Prats-Galino A. Serratus plane block: a novel ultrasound-guided thoracic wall nerve block. Anaesthesia 2013;68(11):1107-13. [CrossRef]

19. Adhikary SD, Bernard S, Lopez H, Chin KJ. Erector Spinae Plane Block Versus Retrolaminar Block: A Magnetic Resonance Imaging and Anatomical Study. Reg Anesth Pain Med 2018;43(7):756-62. [CrossRef]

20. Pusch F, Freitag H, Weinstabl C, Obwegeser R, Huber E, Wildling E. Single-injection paravertebral block compared to general anaesthesia in breast surgery. Acta Anaesthesiol Scand 1999;43(7):770-4. [CrossRef]

21. Sidiropoulou T, Buonomo O, Fabbi E, Silvi MB, Kostopanagiotou $\mathrm{G}$, Sabato AF, et al. A prospective comparison of continuous wound infiltration with ropivacaine versus single-injection paravertebral block after modified radical mastectomy. Anesth Analg 2008;106(3):997-1001. [CrossRef]

22. Boughey JC, Goravanchi F, Parris RN, Kee SS, Kowalski AM, Frenzel JC, Bedrosian I, et al. Prospective randomized trial of paravertebral block for patients undergoing breast cancer surgery. Am J Surg 2009;198(5):720-5. [CrossRef]

23. Fallatah S, Mousa W. Multiple levels paravertebral block versus morphine patient-controlled analgesia for postoperative analgesia following breast cancer surgery with unilateral lumpectomy, and axillary lymph nodes dissection. Saudi J Anaesth 2016;10(1):13-7. [CrossRef]

24. Ohgoshi Y, Ikeda T, Kurahashi K. Continuous erector spinae plane block provides effective perioperative analgesia for breast reconstruction using tissue expanders: A report of two cases. J Clin Anesth 2018;44:1-2. [CrossRef]

25. Apfel CC, Heidrich FM, Jukar-Rao S, Jalota L, Hornuss C, Whelan RP, et al. Evidence-based analysis of risk factors for postoperative nausea and vomiting. $\mathrm{Br} J$ Anaesth 2012;109(5):742-53. [CrossRef]

26. Chiu C, Aleshi P, Esserman LJ, Inglis-Arkell C, Yap E, Whitlock EL, et al. Improved analgesia and reduced post-operative nausea and vomiting after implementation of an enhanced recovery after surgery (ERAS) pathway for total mastectomy. BMC Anesthesiol 2018;18(1):41. [CrossRef] 